Сушкова Ю.Н.

\title{
ГОСУДАРСТВЕННО-ПРАВОВЫЕ ВЗГЛЯДЫ И ПРАВОЗАЩИТНАЯ ДЕЯТЕЛЬНОСТЬ ЛЬВА НИКОЛАЕВИЧА ТОЛСТОГО
}

\begin{abstract}
Аннотация: Лев Николаевич Толстой известен не только как знаменитый писатель, но и общественный деятель, внесший существенный вклад в разработку оригинальных политико-правовых представлений о праве, системе государственного управления, международных отношений, образования и других важных сфер жизни. В предмет исследования входит анализ основных государственно-правовых идей Толстого, его жизненный путь, связанный с непосредственным участием в политических и правовых прочессах. В контексте защиты прав человека Толстой активно представлял интересы русских Духоборов, которые были вынуждены эмигрировать в конце ХІХ-начале XX века из России в Канаду. Многие эпизоды 6 литературных произведениях Толстого написаны по материалам реальных судебных дел, которые продемонстрировали недостатки функиионирования судебной системы, в иелом государственно-правового устройства. Важнейтей идейной концепџией Толстого стал пацифизм, отказ от военных действий в пользу дипломатического и мирного урегулирования конфликтов. Лев Николаевич большое внимание уделял анализу соииальной структуры российской деревни, обычного права крестьян и их взаимоотношения с органами государственной власти. Политико-правовые воззрения Толстого стали уникальным источником подходов и знаний для совершенствования современной модели правовой системы России, преодолению таких актуальных проблем как правовой нигилизм, коррупция, бюрократизм. Его литературное наследие содержит глубокие философские, методологические, фундаментальные идеи о сущности жизни, назначения человека, роли религии, гражданских и государственных институтов, которые могли бы рассматриваться как "вечные темы”, постоянно привлекающие интерес многих поколений в поиске истинных иенностей и констант жизни. Анализ наиболее значимых аспектов темы проводился на основе исторического, формально-юридического, сравнительно-правового методов научного исследования. Делая выводы проведенного исследования, следует подчеркнуть, что Толстой был последовательным и убежденным антигосударственником. В своих художественных творениях Толстой апеллировал к народу как носителю истинной веры и нравственности, считая его основой всего общественного здания. На мировоззрение Толстого оказали огромное влияние Руссо, Кант, Шопенгауэр. Разнообразные взгляды Толстого оказались созвучными определенной части русского и зарубежного общества, выраженном в религиозно-политическом движении толстовства, идеями которого были не только сугубо религиозные, но и общественно-политические, главным образом связанные с идеями пацифизма, «ненасильственных методов» борьбы за равенство и соииальную справедливость. Религиозно-философские идеи Толстого стали концепцией движения толстовства, основанного на началах «опрощения» и «непротивления злу насилием». Последователи его учения почитали провозгламенные им пять заповедей: не гневайся, не прелюбодействуй, не клянись, не противься злу насилием, возлюби врагов своих как ближнего своего. $B$ последние годы жизни Толстого его борьба против несправедливого общественного устройства и его охранителей приобрела поистине титанический и героический характер.
\end{abstract}

Ключевые слова: Лев Николаевич Толстой, толстовство, права человека, правозащитная деятельность, пацифизм, Духоборы, государственно-правовые взгляды, антигосударственник, народ, судебная реформа.

Abstract: Leo Tolstoy is famous not only as a writer, but also as a public figure who has made a significant contribution to the development of original political and legal ideas about the law, the system of public administration, international relations, education and other important spheres of life. The subject of the study includes the analysis of the main state-legal ideas of Tolstoy, as well as his life path associated with direct participation in the political and legal processes. In the context of the protection of human rights, Tolstoy actively represented the interests of Russian Doukhobors who were forced to emigrate in the late XIX and early $X X$ centuries from Russia to Canada. Many of the episodes in Tolstoy's literary works written according to the materials of the real judicial cases, which demonstrated the shortcomings of the justice system and the state 
legal system as a whole. The most important ideological concept of Tolstoy is pacifism, the rejection of military action in favor of diplomatic and peaceful conflict resolution. Tolstoy paid great attention to the analysis of social structure of the Russian village, customary law of the peasants and their relationship with the public authorities. Political and legal views of Tolstoy have become a unique source of knowledge and approaches to improve the modern model of the Russian legal system, to overcome such issues as the legal nihilism, corruption, and bureaucracy. His literary legacy contains profound philosophical, methodological, and fundamental ideas about the nature of life, purpose of man, the role of religion, civil and state institutions, which could be regarded as "eternal themes", constantly attracting the interest of many generations in search of true values and constants of life. Analysis of the most important aspects of the topic were based on historical, formal-legal, comparative legal methods of scientific research.

Keywords: State and legal views, Doukhobors, pacifism, human rights protection, human rights, Tolstoy studies, Lev Nikolaevich Tolstoy, antistatesman, people, judicial reform.

\section{Введение.}

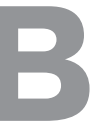
семирно известный писатель, автор романа «Война и мир», «Анна Каренина», «Воскресение» и других произведений Лев Николаевич Толстой выступал с сокрушительной критикой несправедливого общественного строя, правящих классов и казенной церкви, для которых он был «бунтовщиком» и «еретиком». Его художественные произведения, литературные статьи, философские эссе, мемуарная литература, публицистика составляют богатое уникальное историкокультурное наследие России, содержащее в себе огромный пласт разнообразных идей, оказывающих и поныне огромное влияние на духовную жизнь общества. В условиях политико-правовых изменений, роста социальной напряженности, определенной деформации духовно-нравственных ценностей взгляды Толстого на общество, государство, человека, его смысл жизни, назначение и самосовершенствование обретают особо важное научное и практическое значение.

Деятельность Толстого осуществлялась на рубеже XIX-XX веков в эпоху бурного подъема прогрессивной общественно-демократической мысли, роста социально-политического движения, реформ, открывших новые возможности для государственно-правового развития России. Большое внимание в творчестве и размышлениях Льва Николаевича уделяется судьбе своего русского народа, деревне, поиску пути для справедливого обустройства жизни каждого человека. Обращение к наследию Толстого вызвано необходимостью всестороннего осмысления достижений мыслителя, поскольку многие аспекты социально-экономического и политико-правового положения России того периода не утратили своей актуальности и на современном этапе. Оригинальные воззрения Толстого могут не только восстановить знания о политико-правовых подходах к осмыслению юридически значимых явлений, но и стать стимулом для дальнейшего развития и углубления современных научных представлений об обществе, политике, государстве, праве и законодательстве.

История проблемы. Феномен Толстого является предметом постоянного научного изучения на протяжении более ста лет, что привело к становлению не только особого религиозного направления - «толстовства», но и междисциплинарной отрасли знания - “толстововедения”. Историография творчества Толстого огромна, ее золотой фонд составили работы библиографов, писателей, публицистов, литературных критиков, мыслителей и педагогов. В годы советской власти произведения Толстого нередко рассматривались в контексте идеологических установок, что не позволяло исследователям объективно подойти к изучению многих граней деятельности Толстого, раскрыть истинный смысл взглядов. На современном же этапе исследования наследия Толстова продолжаются, постепенно восполняя имеющиеся «белые пятна». По свидетельству одной из ведущих российских литературоведов Лученецкой-Бурдиной, его художественное творчество поныне остается одной из нерешенных проблем отечественного литературоведения [19, с. 3]. Что же касается религиозно-философских, политико-правовых взглядов Толстого, то их можно отнести к малоразработанным аспектам наследия великого писателя.

К числу наиболее известных историкобиографических, литературоведческих, философских, педагогических, религиозных исследований Толстого советского и современного периодов можно отнести работы Галаган (1984), Ломунова (1991), Тарасова (1998), Журиной (2002), Лученецкой-Бурдиной (2002), Глущенко (2004), Гулина (2004), Ореханова (2012) [2, 18, 27, 8, 19, $3,5,6,21,22,23]$. Так, Галаган обратила внима- 
ние на нераздельность Толстого как художника и мыслителя, пристально изучавшего внутренние устремления русского патриархального крестьянина, его традиционный уклад жизни, считая, что народ представлял собой «самосозидающую силу». В своем творчестве писатель рассматривал проблему творческого решения взаимосвязи этического и эстетического, придавав существенное значение нравственным аспектам жизнедеятельности человека, его религиозному мировоззрению. Толстой показывал, что люди постепенно могут привыкать к соблюдению элементарных, веками известных, тысячелетиями повторяющихся во всех прописях, правилах поведения, к соблюдению их без насилия, без принуждения и подчинения, особого аппарата для принуждения, называемого государством [2, с. 11-12, 22].

Гулин справедливо подчеркнул, что философия и взгляды Толстого невозможно рассмотреть вне религиозного строя его личности, ибо «своеобразие толстовского исповедания, веры, сложность его отношения к действительности во многом обусловили исключительную самобытность личности великого творца» [6, с.3]. Большое значение в становлении личности Толстого имел его постоянный поиск собственного предназначения. Паперно отмечает, что во всех произведениях Толстого, от его первых дневников до религиозных трактатов, проявляется сущностная этическая и социальная составляющая проблемы самосовершенствования. Он верил, что в нравственном пространстве самопознание определяется предназначением себя в этом мире, то есть ответом на вопрос «что я должен делать?» (Толстой позаимствовал эту фразу у Канта). Он рассматривал эту проблему в ряде сочинений. Толстой в течение своей жизни пытался найти адекватные способы представления себя, своих возможностей и, в конечном счете, для достижения самосознания, основанного не только на физическом потенциале, но и приобретенном жизненном опыте [39, с. 5].

Орехановым осуществлено комплексное исследование религиозно-философских представлений Л. Н. Толстого, выявлены характерные историкокультурные аспекты его реформаторской деятельности в попытках новой интерпретации Евангелия и христианского вероучения в целом, проанализированы место и роль личности и мировоззрения писателя в контексте конкретной историко-культурной ситуации в России на рубеже XIX - XX вв. $[21,22,23]$. Журина акцентировала внимание на сохранение актуальности справедливого заклю- чения Луначарского, называвшего «Resurrection» социально гениальнейшим романом. Она отмечает, что на страницах романа одна за одной выдвигались социальные проблемы, выступавшие материалом произведения, освещение которого осуществлялось Толстым не на социальном, а на «трансцендентном уровне», социальное зло понималось как частное проявление мирового, универсального зла, возникающего там, где утрачена истинная вера [8, с. 3].

Важное место в историографии исследований о Толстом занимают публикации выдающихся представителей русской религиозно-философской школы, систематизированные в сборниках «О религии Льва Толстого» (1912), «Л.Н. Толстой в воспоминаниях современников» (1978), «Л.Н. Толстой: pro et contra: Личность и творчество Льва Толстого в оценке русских мыслителей и исследователей. Антология» (2000) [20, 13, 14, 15].

Вместе с тем при обилии различных исторических, филологических, культурологических, педагогических, философских исследований, направленных на освещение тех или иных аспектах творчества Толстого, специальные работы, посвященные собственно общественно-политическим, государственно-правовым взглядам в как в отечественной, так и мировой науке отсутствуют.

При анализе правовых воззрений Толстого, его правозащитной деятельности наибольшей интерес представляет статья известного судебного и государственного деятеля, председателя и прокурора Петербургского окружного суда Анатолия Федоровича Кони, написанная на основе личного общения с великим писателем. При первой встрече с Толстым Кони обратил особое внимание на «проницательный и как бы колющий взгляд строгих серых глаз, в которых светилось больше пытливой справедливости, чем ласкающей доброты, одновременный взгляд судьи и мыслителя» [11, с. 175]. Кони поведал писателю немало случаев из судебной практики, которые легли в основу его художественных произведений. Научнопрактический интерес для данного исследования также представляют публикации, осветившие более подробно отдельные аспекты правовых и религиозно-правовых взглядов Толстого, таких авторов как Куприц (1978), Емельянова (1979), Donskov (2005), Багаутдинов (2010), Сушкова (2013) $[12,9,31,1,26]$.

Теоретико-методологические и методы исследования. Политико-правовые отношения и институты являются объектами исследования 
различных гуманитарных наук (юриспруденции, истории, философии, социологии, политологии и других), причем каждая наука с учетом своеобразия предмета и метода, находясь в системе междисциплинарных связей и взаимовлияния, отличается своим специфическим подходом. В наследии Толстого можно выявить размышления, в которых отражены природа, понятие, сущность, ценность, функции и роль различных государственно-правовых институтов, а также юридические аспекты частного или отраслевого профиля (например, о преступлении и наказании, вине и формах ответственности, субъектах права, формах организации, роли и полномочиях суда, источниках судебных доказательств, формах и направлениях административной деятельности).

При изучении сущности политико-правовых взглядов и юридических аспектов деятельности Толстого автором были взяты за основу современные теоретико-методологические подходы, выработанные, главным образом, историей политических и правовых учений. В рамках этой науки используется богатый арсенал как философских, так и специально-научных методов, в числе которых диалектический, исторический, формальнологический, системный, сравнительный, при этом каждая политико-правовая теория обладает в меру своей фундаментальности, научной значимости потенциалом и функцией метода для последующих концепций [4, с. 7-13].

Традиционным научным подходом, рассматривающим государственно-правовые институты, взгляды об их сущности в их эволюционном развитии является диалектический. В представлениях Толстого, в целом отрицавшего государственноправовые институты как таковые, наблюдается определенный идеализм, основанный на первичности не материального, а духовного и признающий единственной реальностью или индивидуальное сознание, субъективное восприятие и ощущение или духовное, идеальное начало, стоящее над всем сущим, в конченом итоге, - бога. В результате многолетних размышлений Толстой сформировал и собственные религиозные воззрения.

В современной литературе существует множество взглядов на понимание права и государства, эффективности организации и деятельности государственно-правовых институтов. Взгляды Толстого уникальны по своей сущности, но им отчасти созвучны позиции исторической школы права, представители которой считали, что юриспруденция должна отражать результаты многовекового опыта эмпирического и духовного познания народом окружающей действительности, формирования им самобытной системы соционормативного регулирования.

Осмысление взглядов Толстого осуществляется на основе принципов историзма и объективности, обусловливавшие всестороннее рассмотрение политико-правовых воззрений Толстого в контексте его биографии, творческий и общественной деятельности на базе широкого круга источников с учетом междисциплинарных подходов, сложившихся в ходе литературоведческих, религиоведческих, правовых, философских научных дискурсов. Взгляды изучаются во взаимопроникновении историко-культурных особенностей развития российского социума второй половины XIX века, которому присуще складывание нового типа личности, рационализация отношения к духовной сфере жизни человека, секуляризация политической и общественной жизни.

Принцип историзма способствует анализу развития институтов с учетом конкретных исторических условий, особенностей, национальной самобытности развития России, позволяет проследить генезис развития тех или иных правовых воззрений, определения их места и значения для определенной эпохи, связей с другими концепциями. Исторический подход выступает в качестве способа осмысления, интерпретации и оценки политико-правового содержания учения в контексте прошлого и современности, позволяет выявить в рассматриваемых идеях «исторические константы». Многие суждения и оценки сложились как теоретико-концептуальные основы, не ушли в прошлое, а, напротив, пережили свое время, стали необходимым звеном в исторической цепи развития и углубления политико-правового знания и являются составным моментом современных теоретических воззрений и построений. Историкоантропологический метод позволяет проследить особенности духовной природы Толстого и процесс формирования его взглядов.

Конкретно-исторический аспект политикоправового содержания учения демонстрирует историческую обусловленность конкретных взглядов на общество, государство, право, политику в представленном учении. Творческое наследие Толстого содержит глубокие философские, общеметодологические, фундаментальные идеи о смысле жизни, миссии человека, роли религии, предназначении государственно-правовых учреждений, являющиеся «вечными темами», 
в разработку которых различные мыслители вносили свой вклад, содействуя тем самым их исторической преемственности и обогащению теоретического пласта различных концепций. В числе сущностных проблем можно также назвать соотношение морали и политики, личности и государства, реформы и революции, власти и насилия, справедливости, равенства и права, права и свободы, права и закона. Историко-генетический метод позволяет раскрыть изменения в содержании политико-правовых, религиозных взглядов Толстого, выявить устойчивые позиции, которым мыслитель следовал на протяжении всей жизни.

Сравнительный (компаративистский) метод способствует выделению своеобразия взглядов Толстого в сравнении со взглядами его современников в России и в Европе. Сопоставительный анализ (в синхронном и диахронном плане) различных концепций, конкретизируя знания об их общих и специфических чертах, содействует выявлению более точных критериев классификации и типологизации политико-правовых учений и, следовательно, более верной оценке их содержания [4, с. 13]. Например, широко известен спор между Толстым и Соловьевым, в рамках которого Соловьев требовал включения государства в Царство Божие, Толстой же настаивал на необходимости совершенного его упразднения. Вопрос между двумя мыслителями ставился таким образом: теократия или анархия, святая государственность, подчиненная церкви или полное отрицание государства [20, с. 59-76; 35 , с. 360-380].

Юридические аспекты деятельности Л.Н. Толстого и его политико-правовые взгляды. Путь социального прозрения начался еще в стенах Казанского университета в годы студенческой юности Толстого, когда он с 1845 года начал учебу на первом курсе юридического факультета, где пытался найти объяснения явлениям современного правового быта. Одним из наиболее ярких ученых Казанского университета того периода был один из создателей науки гражданского права Д.И. Мейер, давший задание молодому Толстому проанализировать «Наказ» Екатерины II и сравнить его с произведением Монтескье «О духе законов». В результате этой самостоятельной работы Толстой проявил позитивное отношение к республиканской форме правления, отрицание самодержавия, деспотизма, рабства. Определенный интерес у него вызывали уголовно-правовые науки, в частности, во время обсуждения вопроса о смертной казни он высказывал к этому виду уголовной кары резко отрицательное отношение.
Вместе с тем он не смог найти в университетских науках ответов на волновавшие его вопросы. Ограниченность учебного курса, сориентированного Уставом 1835 г. на изучение только действующих российских законов, не оставляла места философскому аспекту права; историко-правовое направление, способное оживить сухую догматику, только еще зарождалось. «В письме студенту о праве», написанном незадолго до смерти, в 1909 г., Толстой писал: «Я ведь сам был юристом и помню, как на втором курсе меня заинтересовала теория права, и я не для экзамена только начал изучать eе, думая, что найду в ней объяснение того, что мне казалось странным и неясным в устройстве людей. Но помню, что чем более я вникал в смысл теории права, тем все более и более убеждался, что или есть что-то неладное в этой науке, или я не в силах понять ее» $[17$, с. 60]. Не явившись на зимние экзамены второго года обучения на юридическом факультете, Толстой весной 1847 г. подал заявление об отчислении из университета; в качестве официальных причин ухода он назвал расстроенное здоровье и домашние обстоятельства. Правоведом он не стал, но в его гениальных произведениях вопросы права, закона, правосудия, власти, социального неравенства занимают важнейшее место [12, с. 97-105]. Для всего его творчества характерна безбоязненная, открытая, беспощадно резкая постановка самых больных, самых проклятых вопросов того времени.

Известно об отдельных фактах непосредственного участия писателя в осуществлении юридической деятельности, правосудия. Например, в 1861 г., в связи с отменой крепостного права, Толстой был назначен мировым посредником 4-го участка Крапивинского уезда Тульской губернии. По сегодняшним меркам он осуществлял функции мирового судьи. В отличие от тех, кто смотрел на народ как на младшего брата, которого надо поднять до себя, Толстой думал наоборот, что народ бесконечно выше культурных классов и что господам надо заимствовать высоты духа у мужиков, поэтому он, приняв должность посредника, активно защищал земельные интересы крестьян, часто нарушая царские указы. «Посредничество интересно и увлекательно, но нехорошо то, что все дворянство возненавидело меня всеми силами души и суют мне des batons dans les roues (фр. палки в колеса) со всех сторон [16, с. 572]. Работа посредником расширила круг наблюдений писателя за жизнью крестьян, предоставив ему материал для художественного творчества. Толстой разби- 
рал различные споры между помещиками и крестьянами. Работа Толстого на этом участке была недолгой, помещики обратились к предводителю дворянства с ходатайством об устранении его от обязанностей мирового посредника. Помещики утверждали, что Толстой решает дела в пользу крестьян. По этой причине писателю пришлось оставить эту должность [1, с. 24].

Выступал он и в качестве защитника по уголовному делу. В июле 1866 г. недалеко от усадьбы Толстого в пехотном полку писарь Шабунин ударил командира полка и был предан военно-полевому суду. Ему грозила смертная казнь. Сослуживцы попросили писателя выступить в качестве защитника, он согласился. Из обстоятельств дела следовало, что командир полка на протяжении нескольких месяцев постоянно устраивал различные придирки к писарю и довел его до крайней степени раздражения, в результате тот не сдержался и ударил командира. Толстой в своем выступлении постарался убедить суд в том, что Шабунин - душевнобольной человек и заслуживает снисхождения. Однако участие его в этом деле не имело успеха - обвиняемого приговорили к расстрелу [7, с. 658663]. Этот эпизод произвел большое впечатление на Толстого, так как он в данном страшном явлении видел беспощадную силу, которую представляло собою государство, основанное на насилии. По этому поводу они писал своему другу публицисту Бирюкову: «Случай этот имел на всю мою жизнь гораздо более влияния, чем все кажущиеся более важными события жизни: потеря или поправление состояния, успехи или неуспехи в литературе, даже потеря близких людей» [7, с. 663].

Кроме этого, Толстой неоднократно посещал судебные заседания, в том числе и с участием присяжных заседателей. Известно, что он и сам участвовал в рассмотрении отдельных уголовных дел как присяжный заседатель. 18 июня 1881 года Толстой посетил по делам Калужский окружной суд. После посещения суда он записал в дневнике: «Ходил в окружной суд. Вся та же канитель. Бедняк украл полушубок. Его - в арестантские роты на 3 года и 9 месяцев». В дневнике за 27 ноября 1890 г. писатель пишет о судебном процессе в Крапивинском суде Тульской губернии, характеризуя суд как «стыдную комедию». Сюжеты таких произведений Толстого, как «Воскресение», «Живой труп», «Власть тьмы»», взяты из реальной судебной практики 80-90-х гг. ХІХ в.

Толстой был дружен с председателем Московского окружного суда Н.В. Давыдовым, при со- действии которого неоднократно посещал тюрьмы, беседовал с заключенными. Л. Толстой писал письма, ходатайства судебным и государственным чинам, вплоть до царя, в защиту арестованных, политических заключенных, ссыльных. Именно Давыдов рассказал Толстому об уголовном деле супругов Гимер, которые, чтобы получить развод, инсценировали самоубийство мужа. Так появилась драма «Живой труп». В этом произведении мы видим великолепное описание сцен допросов. Немало публицистических статей Л. Толстого посвящено вопросам права, правосудия, справедливости («Стыдно», «Письмо студенту о праве», «Царю и его помощникам» и др.). Против царского суда, против казней участников революции 1905 г. направлены известные статьи Л.Н. Толстого «Не могу молчать» и «Кто убийцы?» [1, с. 26].

Но особое место в жизни и творчестве Толстого занимает дружба с Анатолием Федоровичем Кони. В своей статье он отмечал, что «глубокую наблюдательность» Толстого не следует смешивать с «острой проникновенностью психологического анализа» Достоевского. В своих произведениях Толстому удавалось подметить и изобразить в самых разнообразных явлениях жизни и в действиях людей стороны или черты, ускользавшие в повседневной жизни от взора читателя, который поражался «знаменательною правдивостью» их описаний в ярких художественных образах. В работах Толстого всегда звучал голос «неотразимой житейской правды», ибо он рассматривал одновременное проявление в людях как высоких порывов их духа, так и низменных сторон человеческой природы. В анализе противоречивости природы человека Толстой видел свою задачу и основное свойство своего творчества. По этому поводу Толстой размышлял: «Тяжелое раздумье одолевает меня. Может, не надо было говорить этого. Может быть, то, что я сказал, принадлежит к одной из тех злых истин, которые, бессознательно таясь в душе каждого, не должны быть высказываемы, чтобы не сделаться вредными, как осадок вина, который не надо взбалтывать, чтобы не испортить его. Где выражение зла, которого надо избегать? Где выражение добра, которому должно подражать в этой повести? Кто злодей? Кто герой ее? Все хороши и все дурны... Герой же моей повести, которого я люблю всеми силами души, которого старался воспроизвести во всей красоте его и который всегда был, есть и будет прекрасен, - правда» [10, с. 2-5].

Уникальность личности Толстого заключалась и в том, что он посвящал себя не только 
художественному изображению правды, но поиску и отстаиванию справедливости, главным образом в правовой защите крестьянства. По свидетельству Кони, правозащитная сторона его деятельности не менее значительна, чем художественная. «Бестрепетною рукою всегда стремился он в своих драматических произведениях, сказках, рассказах и повестях, в своих философских и этико-политических сочинениях снять обманчивые и заманчивые покровы с житейской и общественной лжи, в чем бы эта ложь ни проявлялась - в теориях и практике, в традициях и учреждениях, в обычаях и законах, в условной морали и безусловном насилии», - писал Кони. Взывая к внутреннему миру человеку, призывая его «совлечь с себя ветхого Адама», он стремился доказать, что «царство божие» основано на духовных потребностях, независимо и даже вопреки сложившимся условиям человеческого общежития. Читатель может не соглашаться с отдельными положениями Толстого или сильно сомневаться в возможности их целесообразного осуществления на практике, но «нельзя не отнестись с горячим уважением к писателю, который не удовлетворяется заслуженною славой великого художника, а стремится всею силою своего таланта служить разрешению назревающих вопросов жизни, во имя и с целью уменьшения страданий и господства действительной, а не формальной только справедливости». Ко всем жизненным вопросам о смысле жизни, призвании человека, семье, воспитании, отношения к смерти и другим Толстой подходит с глубокой верой в нравственную ответственность человека, необходимостью постоянного духовного самоусовершенствования. Мыслитель стремился к пробуждению совести, рассматривая лишь ее «верховным судьей жизни, побуждений и деятельности человека». В своих художественных произведениях и философских эссе Толстой обращался к голосу тайников человеческой души, и, действуя страстным словом или яркими образами, блещущими правдивостью, «заставлял этот голос звучать настойчиво и долго». Этой способностью исключительного художественного мастерства, по мнению Кони, обусловливалась популярность его имени и трудов далеко за границами России в Западной Европе и в Америке [10, с. 2-5].

Кони поведал писателю один случай из собственной практики. В первой половине семидесятых годов к нему как прокурору Петербургского окружного суда обратился молодой дворянин, назначенный позднее вице-губернатором одной из губерний России, с просьбой оказать содействие в заключении брака с арестанткой Розалией Онни, за плечами которой было не только совершенное преступление, но и в целом темное и тяжелое прошлое. Вступив с ним в частный разговор Кони поинтересовался мотивами намерения, но так и не получил ответа. Ранее ему приходилось слышать признания и заявления о совершенных или планировавшихся преступлениях, побуждения к которым имели неординарный характер. Лишь спустя некоторое время после внезапной смерти в тюрьме от сыпного тифа Розалии смотрительница женского отделения поделилась с Кони историей о судьбе этой несчастной девушки. В память о Розалии жених пожертвовал подготовленное для нее приданое в пользу приюта арестантских детей женского пола.

Оказалось, что Розалия была дочерью вдовца, арендатора в одной из финляндских губерний. После его смерти до 16 лет она была принята в «девичий дом», в котором познакомилась с этим молодым человеком, впоследствии ставшим женихом тюремной сиделицы. Будучи родственником хозяйки, при удобном случае, он соблазнил несчастную девушку, после чего ее выгнали из дома. Брошенная затем своим соблазнителем, она родила, отдала ребенка в воспитательный дом и стала «спускаться со ступеньки на ступеньку», покуда не очутилась в притоне около Сенной. Молодой же человек переселился в Петербург и вступил в «общую колею деловой и умственной жизни». Однажды, будучи присяжным окружного суда, во время разбирательства он узнал в обвиняемой в краже проститутке жертву своей «молодой и эгоистической страсти». В душе этого человека произошел перелом, во искупление своего греха он решился пожертвовать «свободой», «именем» и «каким-либо другим глубоким чувством» ради реализации «права на наказание». Глубокий и сокровенный смысл этого происшествия оставил в Кони сильное впечатление. По его свидетельству, «это было не простым случаем, а было откровением нравственного закона, было тем проявлением высшей справедливости, которая выражается в пословице: «Бог правду видит, да не скоро скажет» [11, с. 184-188].

Рассказ о деле Розалии Онни произвел на Толстого сильное впечатление. В августе 1895 г. Л.Н. Толстой сообщил Анатолию Федоровичу: «Пишу я, правда, тот сюжет, который вы рассказывали мне, но я так никогда не знаю, что выйдет из того, что я пишу, и куда оно меня заведет, что я 
сам не знаю, что я пишу теперь». В 1898 г. Толстой принял решение использовать доходы от своей работы, чтобы помочь переселиться в Канаду угнетенным сектантским группам, известным как Духоборы. Он стал сосредоточенно работать над романом, который “вырос из рассказа о вине за неблагоразумный поступок в произведение эпического размаха, панорамное изображение жизни Российского государства в конце девятнадцатого века, представленном с уникальной точки зрения Льва Николаевича Толстого” [34, с. Viii].

В течение десятилетия, в котором он писал “Воскресение”, в последнее десятилетие 19-го века, Толстой сам был в путешествии открытий, пробужденный интересом к социальным, экономическим и политическим проблемам общества. Роман “Воскресение" в наибольшей степени из других художественных произведений Льва Николаевича отображает его социальные, этические и религиозные взгляды. Это мировоззрение сложилось под влиянием одной фундаментальной концепции, впервые проявившаяся в 1860-е гг. в эссе Толстого об образовании, а затем, особенно в десятилетие «Воскресения», стала доминировать в его социальной и политической мысли. Речь идет о концепции насилия, предполагающего, на манер Толстого взрослеющего интеллектуального последователя Руссо, физическое и духовное принуждение, в результате которого природная невинность человеческой доброты искажается культурными и социальными институтами. Правительство такого общества является организационным воплощением фундаментального принуждения/насилия, оно держится его основным механизмом обеспечения - армией, которая сама по себе является системой, превращающей людей из невинных ремесленников в чудовищных бестий. Невоенными же институтами, в который в наибольшей степени воплощено это насилие - правовая система с ее судами и пенитенциарными учреждениями”, - пишет в своей работе Густафсон [34, с. viii, ix].

Церковь, которая должна отстаивать основополагающие учения Христа, по сути, издевается над ними, потворствуя войнам и милитаризму, поддерживая правовую систему, заключение в тюрьмы и смертную казнь, и сама по себе ставит в тупик умы людей через пьянящую литургию и помпезные церемонии. Общество может быть искуплено от этого порядка насилия только тогда, когда все признают свою причастность к нему и договорятся перестать ненавидеть, мучить, порабощая и убивая. Именно это мировоззрение препятствует воскрешению. Густафсон приходит к выводу, что роман “Воскресение” уникален тем, что в нем сочетается анатомия социального с историей нравственного пробуждения и духовного роста на пути к свободе от светских идеалов и к возможности новой жизни. "Воскресение” построено на контрастах опыта героини и героя, бедного и богатого, аутсайдеров и инсайдеров, жертв и преступников, заботы и черствости" [34, с. іх-х].

Через одиннадцать лет в свет вышло «Воскресение», произведшее, по свидетельству Кони «сильнейшее впечатление на души многих молодых людей и заставившее их произвести по отношению к самим себе и к житейским отношениям нравственную переоценку ценностей». Это произведение нередко называлось Толстым «Кониевской повестью». В романе много места уделено описанию судебного заседания, нравов и порядков тогдашней судебной системы. При описании процесса суда, образов судей, присяжных заседателей, подсудимых писатель опирался на реальные события и факты, использовав реальные протитипы персонажей [37, с. 1-1]).

Л.Н. Толстой относился с осуждением некоторых сторон в деятельности судов. «Воскресение» послужило впоследствии выражением его правовых взглядов. Со сдержанным негодованием он рассказывал о своем опыте призыва в качестве присяжного заседателя в Тулу, а также отдельных эпизодов судопроизводства, поведения участников процесса, судей и адвокатов. Мировоззрение Кони совпадало с позициями Толстого относительно необходимости соблюдения в юридической практике этических норм. По этому поводу Кони отмечал: «Показная и, если можно так выразиться, в некоторых случаях спортивная сторона в работе обвинителей и защитников всегда меня от себя отталкивала, и, несмотря на неизбежные ошибки в моей судебной службе, я со спокойною совестью могу сказать, что в ней не нарушил сознательно одного из основных правил кантовской этики, то есть не смотрел на человека как на средство для достижения каких-либо, хотя бы даже и возвышенных, целей». Кони полагал, что Толстой оценил его порядочность и относился к нему очень по-доброму, с глубоким уважением и благодарностью за юридическую помощь в защите крестьян. Анатолий Федорович, будучи идейным последователем Канта, большое внимание уделял разработке проблем судебной этики. Он считал, что осуществление безусловных требований нравственного долга выражается прежде всего в 
уважении к человеческому достоинству и в любви к человеку как к носителю нравственного закона, в основе которого лежит «счастье ближнего и собственное нравственное совершенство». Кони показывал Толстому работу, посвященную судебной этике. «Судебную этику я прочел, - отвечал он ему в 1904 году, - и хотя думаю, что эти мысли, исходящие от такого авторитетного человека, как вы, должны принести пользу судейской молодежи, но все-таки лично не могу, как бы ни желал, отрешиться от мысли, что как скоро признан высший нравственный религиозный закон - категорический императив Канта,- так уничтожается самый суд перед его требованиями. Может быть, и удастся еще повидаться, тогда поговорим об этом. Дружески жму вашу руку» [11, с. 188-189].

Через процесс воскресения, духовного возрождения прошли не только герои романа «Воскресение», но в целом народ России. Именно раннюю стадию его «воскресения» и стремился запечатлеть великий писатель, называвший себя «адвокатом 100-миллионного земледельческого народа». Все позднейшее творчество Толстого проникнуто убеждением, что жизнь должна быть существенно преобразована. В свете идей Толстого его роман должен восприниматься не как роман-утопию, а роман-предвидение, романпредвестие. В нем, как и в других публицистических работах 1890-х годов, Толстой возвестил о неизбежности народной революции в России, полагая, что она будет, прежде всего, крестьянской. Он создавал «Воскресение» как «совокупное письмо», обращенное к миллионам читателей. И писатель не ошибся, полагая, что с романом познакомятся как в России, так и зарубежных странах мира. Полный текст романа печатался за рубежом огромными тиражами. В начале января 1900 г. газета «Россия» сообщала о том, что роман Толстого читали «разом, вместо десятков тысяч, сотни тысяч людей», «он проникал в массы небогатых читателей, до которых нередко вести о выдающихся явлениях литературы доходят из вторых рук». Через год после первых публикаций Толстой заметил одному из московских журналистов, что его роман «Воскресение» доставил ему чувство глубокого удовлетворения, поскольку сумел выразить давние размышления и круг читателей оказался огромным [18, с. 8-12; 42, с. 15-26].

Толстой разработал особую идеологию ненасильственного анархизма, которую нередко называют христианским. Он считал принуждение злом и сделал вывод о необходимости упразднения го- сударства, но не путем революции, основанном на насилии, а путем отказа каждого члена общества от исполнения государственных обязанностей, таких как воинская повинность, уплата налогов. Л. Н. Толстой писал: «Анархисты правы во всем: и в отрицании существующего, и в утверждении того, что при существующих нравах ничего не может быть хуже насилия власти; но они грубо ошибаются, думая, что анархию можно установить революцией» [28, с. 211-230]. Политические и правовые взгляды Н. Толстого развивались в результате и его опыта участия в Крымской войне, осаде Севастополя, после которых он стал пацифистом. А, став свидетелем публичной казни в Париже в 1857 году, он пришел к убеждению подлинного отрицания государственно-правового устройства [40].

Логической экстраполяцией учения Толстого о пацифизме, отвергающем любое насилие, в том числе самозащиту и возмездие, стала теория непротивления злу. Под влиянием этой теории было начато целое Толстовское движение, имевшее немало последователей не только в России, но и за ее пределами. Сподвижники толстовства организовывали общины, в которых люди следовали идеалам их кумира. Важнейшим аспектом доктрины Льва Николаевича было отрицание государства и всех его учреждений, поскольку они по своей сути действовали с помощью насилия и угнетения. Насилие использовали не только такие институты, как полиция и армия, но и, например, налоговые органы, потому что они укореняли неравенство и превосходство одних над другими. Церковь была также включена в этот процесс, так как она поддерживает другие функции государства $[29,41$, с. 42-52; 44].

Важнейшим вопросом государственно-правового регулирования в России был земельный вопрос. Толстой считал, что проблему земли, а точнее «земельного рабства», следует рассматривать не столько как политико-правовую, сколько как морально-этическую, нарушающую «первобытные требования нравственности». В письме от 6 ноября 1909 г. он отмечал, что его поражала существовавшая «вопиющая несправедливость земельной частной собственности», «глупое, дерзкое решение этого вопроса, которое принято нашим несчастным правительством, и то полное непонимание его людьми общества, считающими себя передовыми». «Мне думается, что вопрос о несправедливости земельного рабства и о необходимости освобождения от него стоит теперь 
на той же степени сознания его, на которой стоял вопрос крепостного права в 50-х годах: такое же сознательное возмущение народа, живо сознающего совершаемую над ним несправедливость, такое же сознание этой несправедливости в редких лучших представителях богатых классов и такое же грубое, отчасти не умышленное, отчасти умышленное непонимание вопроса в правительстве», - писал Толстой. Правительству следовало бы понимать, что «русский народ, с своим укоренившимся сознанием о том, что земля божья и может быть общинной, но никак не может быть предметом частной собственности, оно бы поняло, что русский человек стоит в этом важнейшем вопросе нашего времени далеко впереди других народов». Толстой был убежден, что правительству необходимо исполнить великую роль выражения передовых идеалов народа, освободив землю от права собственности, однако, как всегда, «правительственные люди, стоя на самой низкой и нравственной и умственной ступени, в особенности теперь, после победы над революцией, ставшие особенно самоуверенными и дерзкими, не будучи в состоянии ни думать самобытно, ни понимать безнравственности земельной собственности, смело ломают вековые устои русской жизни для того, чтобы привести русский народ в то ужасное, безнравственное и губительное состояние, в котором находятся народы Европы». [25, с. 438-450].

Толстой обладал огромным влиянием на многих известных в мире писателей и мыслителей, и его влияние выходило за пределы литературы в реальную жизнь. Идеи ненасильственного сопротивления оказали существенное влияние на выдающегося деятеля национально-освободительного движения Индии М. Ганди, который называл Толстого своим учителем. В мире, пойманном на дыбе террора и насилия, идеи Льва Толстого имеют колоссальное значение для международного сообщества. Переписка Ганди и Толстого содержит уникальный обмен взглядами на личностное перерождение и его последствия. Ганди с большим энтузиазмом стал последователем Льва Толстого и унаследовал сложный “поиск истины”, которым был занят Толстой на протяжении большей части своей жизни. Преподобный Док пишет в своей биографии о Ганди: “Толстой, несомненно, имел глубокое влияние на него. Старый русский реформатор простотой своей жизни, бесстрашием высказываний, сущностью учений о войне и труде нашел в мистере Ганди добросердечного ученика" [38, p. 12-13].
Многие европейские мыслители, среди которых был австрийский философ Стефан Цвейг считали Толстого “апостолом ненасилия”, пацифизма. По свидетельству Цвейга, призыв Толстого к новому социальному порядку положил начало такому движению, как русская революция и кампанию Махатмы Ганди по освобождению Индии. Учения Толстого были продолжены в знаменитой политике Ганди о ненасилии. Цвейг провозгласил Толстого духовным отцом Ромена Роллана, призывавшего к миру во время Первой Мировой Войны. Оба Толстой и Цвейг отрицали современный милитаризм. Критические подходы Толстого и Цвейга главным образом были направлены против европейского высшего общества и ее порочных ценностей. Для Толстого крестьяне представляли наиболее нравственных людей, находящихся ближе всего к истине. Для Цвейга таковыми были простые евреи Восточной Европы, превосходящие богатых и образованных представителей европейского общества [45; 33, с. 108-115].

Одним из самых активных американских мыслителей, с которыми переписывался Толстой, был судья и писатель Эрнест Хэвард Кросби (18561907). После своего первого знакомства с философией Толстого в 1891 году, Кросби стал одним из наиболее энергичных и преданных сподвижников толстовства в Америке, нападающих на милитаризм в целом и особенно на империалистический (характерный для испано-американской и русскояпонской войн), и социальную несправедливость, провозглашенную именем христианских идеалов. Кросби продолжал идеи Толстого и защищал его литературные интересы, предоставляя ему материалы из американской прессы, призвал его написать в поддержку различных ситуаций и лиц, а также делился собственными сочинениями со своим учителем, в том числе его сатирические антимилитаристский роман “Капитан Джонки, Герой”. Вдохновленный поворотом событий в России на рубеже веков, Кросби выразил желание вернуться в Россию после ожидаемой революции (его первый и единственный визит состоялся в 1894 году), на что Толстой ответил скептически, чтобы он не медлил. Безвременная кончина помешала Кросби вновь встретиться со своим учителем [30, с. 110].

Защита религиозных прав духоборов. В поисках решения жизненно важных вопросов бытия, правды и смысла жизни, Л.Н. Толстой вел беседы со священнослужителями и монахами, ходил к старцам в Оптину пустынь, досконально изучал Евангелие, читал богословские трактаты, изучил 
древнегреческий и древнееврейский языки, чтобы в подлиннике познать первоисточники христианства, как одной из мировых религий [43]. Вместе с тем он внимательно присматривался к инаковерующим, так называемым еретикам, в том числе и раскольникам - духоборам, молоканам, баптистам, всем тем, кто носил обобщающее название сектантов. Толстой очень интересовался убеждениями и историей духоборов, в частности, концепцией “единства народа”, воплощенной на их примере. Для Толстого духоборы представляла собой живой пример “практического христианства” как движения религиозного сообщества [31, с. 10-45].

Духовные поиски Л.Н. Толстого привели его к выработке своего нравственно-религиозного учения, суть которого заключалась в идеологии личного самоусовершенствования, основанного на принципе «всеобщей любви», «непротивления злу насилием». Важнейшим социально-правовым институтом Толстой рассматривал семью.

Американский журналист Джордж Кеннан (1845-1924), проведший в Ясной Поляне день (17 июня 1886 г.) в общении с Л.Н. Толстым, полемизируя с писателем, говорил ему, что если угнетение выгодно угнетателю и если он видит, что может безнаказанно угнетать и никто не противится ему, то когда, по-вашему, он должен перестать угнетать? «Мне кажется, что мирное подчинение несправедливости, которую вы защищаете, должно просто разделить общество на два класса: тиранов, которые находят выгодной тиранию и которые поэтому будут продолжать ее бесконечно, и рабов, которые считают сопротивление бесполезным и которые будут вечно подчиняться» [13, с. 374].

«Однако, - писал Д. Кеннан, - граф Толстой продолжал утверждать, что единственный путь уничтожить угнетение и насилие состоит в том, чтобы полностью отказаться вершить насилие, что бы к этому не побуждало. Он сказал, что политика непротивления злу, которую он проповедует как революционный метод, находится в полном соответствии с характером русского крестьянина, и он сослался на широкое и быстрое распространение религиозного сектантства в империи, как на пример успеха такой политики, несмотря на репрессивные меры» [13, с. 374].

Это хорошо понимал и один из влиятельнейших лиц государства обер-прокурор Святейшего Синода К.П. Победоносцев, который писал в 1891 году царю Александру III: «Нельзя скрывать от себя, что в последние годы крайне усилилось умственное возбуждение под влиянием сочинений графа Толстого и угрожает распространением странных, извращенных понятий о вере, о церкви, о правительстве и обществе; направление вполне отрицательное, отчужденное не только от церкви, но и от национальности. Точно какое-то эпидемическое сумасшествие охватило умы» [24, с. 142].

Широкая проповедническая деятельность писателя привела в 1901 г. к отлучению его от православной церкви. Как сказано в Определении Святейшего Синода: «Известный всему миру писатель, русский по рождению, православный по крещению и воспитанию своему, граф Толстой, в прельщении гордого ума своего, дерзко возстал на Господа и на Христа Его и на святое Его достояние, явно перед всеми отрекшись от вскормившей и воспитавшей его Матери, Церкви православной, и посвятил свою литературную деятельность и данный ему от Бога талант на распространение в народе учений, противных Христу и Церкви, и на истребление в умах и сердцах людей веры отеческой, веры православной, которою жили и спасались наши предки и которою доселе держалась и крепка была Русь святая. В своих сочинениях и письмах, во множестве рассеиваемых им и его учениками по всему свету, в особенности же в пределах дорогого отечества нашего, он проповедует, с ревностью фанатика, ниспровержение всех догматов православной Церкви и самой сущности веры христианской, отвергает личного живого Бога, в Святой Троице славимого, Создателя и Про мыслителя вселенной; отрицает Господа Иисуса Христа - Богочеловека, Искупителя и Спасителя мира, пострадавшего нас ради человеков и нашего ради спасения и воскресшего из мертвых; отрицает безсеменное зачатие по человечеству Христа Господа и девство до рождества и по рождестве Пречистой Богородицы Приснодевы Марии, не признает загробной жизни и мздовоздаяния, отвергает все таинства Церкви и благодатное в них действие Святого Духа и, ругаясь над самыми священными предметами веры православного народа, не содрогнулся подвергнуть глумлению величайшее из таинств, святую Евхаристию». В силу этого «Церковь не считает его своим членом и не может считать, доколе он не раскается и не возстановит своего общения с нею» [24, с. 143].

Хотя «нечестие» графа Толстого давно уже осознавалось в церковных кругах, оно особенно стало для них нетерпимым после публикации в 1899 г. его «богохульного» романа «Воскресение». Весь доход от издания его автор отдавал преследуемым царским правительством духоборам, 
переселявшимся в Канаду. Более того, переселявшихся из России в Канаду сопровождал сын Льва Николаевича Сергей Львович Толстой. Это был второй пароход, увозивший в Новый Свет духоборов. Он носил название «Супериор», и на его борту было 1989 переселенцев. В январе 1899 г. пароход благополучно прибыл в порт Галифакс. «Переезд совершился благополучно, - говорил Лев Николаевич Толстой одному из собеседников. - Духоборы, вероятно, хорошо устроятся в Америке. Вера духоборов ближе всего подходит к нравственному состоянию людей, ищущих бога. Лет через 500 те верования, из-за которых духоборы должны были выселиться в Америку, будут господствующими у большинства христианских народов» [14, с. 206, 219, 325, 559, 564, 572].

Как отмечает в своем «Дневнике»дочь Льва Николаевича Татьяна Львовна СухотинаТолстая, будучи в начале 1898 г. в Петербурге и собираясь уже ехать домой, она получила от папы телеграмму: «Молокане приезжают вторник Петербург хлопотать детях. Отложи отъезд помочь им». Речь шла о детях трех мордовских крестьян-сектантов из Самарской губернии Чипилева, Болотина и Самошкина, которые были отняты у родителей и отданы в монастырь. Об этом произволе властей Толстой дважды писал царю: 10 мая и 19 сентября 1897 г. Первое письмо по назначению не дошло, второе было передано Николаю II. Прошение царю написано Толстым 25 января 1898 г. от имени молоканина Ф.И. Самошкина, у которого был отобран единственный пятилетний сын. В это же день Лев Николаевич обратился к известному адвокату А.Ф. Кони с письмом, в котором просил его похлопотать в сенате о возвращении родителям насильно отнятых детей. «Нельзя оставаться спокойным, - писал он, - когда на ваших глазах совершаются такие злодейства». Татьяна Львовна Сухотина-Толстая обратилась по этому поводу к Обер-прокурору Святейшего Синода К.П. Победоносцеву, который при встрече с ней заявил, что «самарский архиерей переусердствовал», отняв детей «у шестнадцати родителей» и что он сейчас же напишет в Самару губернатору. Татьяна Львовна в своей дневниковой записи от 8 марта 1898 г. отметила: «папа получил от молокан письмо, что детей им вернули» [14, с. 222-225, 575].

«Но в те годы, к которым относится большая часть писем Льва Николаевича, людей, имевших смелость, повинуясь голосу совести, не желать укладывать свое религиозное чувство и испове- дание веры в установленные и окаменелые рамки, ждали всякого рода стеснения, обидные прозвища, домогательства носителей меча духовного и воздействия меча светского. И люди эти не были представителями изуверного сектантства, заблуждения которых идут вразрез с требованиями общежития и нравственности: это были по большей части люди глубоко верующие, преданные заветам отцов и дедов и выгодно отличавшиеся от окружающего населения своею трезвостью, любовью к труду, домоводством и нередко строгою семейною жизнью, ныне столь расшатанною... Их страдальческая судьба, испытываемые ими гонения и разрушение их семейного быта, в и в деле отнятия детей и насильственной отдачи их в монастыри, возмущали и волновали Льва Николаевича. Он писал письма к власть имущим, хлопотал о составлении прошений и обращался со словами трогательного заступничества к тем, кому предстояло сказать свое слово по этим делам. В числе последних бывал и я», - писал Кони.

Российские духоборы и молокане подвергались на родине жестоким репрессиям за то, что они отказывались, ссылаясь на свои религиозные убеждения, от службы в царской армии. Молокане допускали возможность службы в армии только в качестве обозников и санитаров. Выдающийся японский писатель Кэндзиро Токутоми, известный под псевдонимом Токутоми Рока (1868-1927) - один из увлеченных последователей Льва Николаевича в Японии, посетивший его в 1906 г., провел в Ясной Поляне пять дней, Токутоми Рока оставил исключительной достоверности воспоминания, содержащие почти протокольные записи всего того, что он там видел и слышал. Воспоминания эти особенно интересны изложением многочисленных высказываний Толстого о важных вопросах литературы, культуры и злободневных общественных проблемах. Так, говоря о воинской повинности и мире, свидетельствует Т. Рока, я сказал: «путь к миру лежит не через Гаагскую конференцию, единственно правильный путь указывает секта духоборов. Если бы все встали на этот путь, не обошлось бы, конечно, без жертв, но они послужили бы благой цели». «Да, это так, - отвечал Толстой. - Однако будет плохо, если кто-нибудь из них открыто возьмется за оружие. Любовь в каждом человеке должна быть настолько велика, чтобы она не позволила взять оружие в руки. И в самом деле, кто может подчиниться, если скажут: отрежь голову младенцу? Любовь к ребенку не позволит этого сделать» [14, с. 325]. 
Особый интерес для историко-правовой науки представляет вторая половина XIX - начало XX в. - период, насыщенный острыми идейными спорами и идеологическими столкновениями и противостояниями, имевшими место на фоне важнейших социально-политических преобразований. Одним из важнейших направлений исторических исследований в этом отношении является изучение жизни, мировоззрения и деятельности крупнейших представителей русской культуры указанного периода, к числу которых относится Толстой. Великий русский писатель, выдающийся мыслитель, художественные, философские и публицистические произведения которого стали известны всему миру и во многом определили образ восприятия России в начале XX в., Толстой проявлял интерес к самым разным сторонам жизни. В его произведениях были сформулированы проблемы личной свободы, мотиваций поведения человека, этические проблемы правосудия, наказания, раскаяния. Во второй половине в жизни Л.Н. Толстого наблюдается кардинальный перелом в религиозно-философских, государственно-правовых взглядах, отношении к смыслу жизни, во многом обусловленный идейным конфликтом с К. П. Победоносцевым и св. прав. И. Кронштадтским. Изучение генезиса, исторической эволюции, идейных особенностей и деталей как внутреннего конфликта писателя, так и внешних противоречий с государственно-властными структурами, церковью является актуальной темой для современных дискурсов. Обсуждение политикоправовых взглядов Толстого позволяет на более глубоком уровне осмыслить процесс развития отечественного государства и права, закона и законности, общественного и государственного устройства, форм взаимоотношений личности и власти, влияния среды на формирование правосознания человека и в целом его правовой культуры.

Выводы. Л.Н. Толстой (1828-1910) - великий русский писатель, мыслитель, общественный деятель, чье творчество оставило глубокий след в жизни России. Сущность познания Толстой видел в уяснении смысла жизни, призванного ответить на многие другие вопросы бытия. Подвергая критике общественно-политическое устройство современной ему России, Толстой уповал на нравственно- религиозный прогресс в сознании человечества. Идею исторического прогресса он связывал с решением вопроса о назначении человека, ответ на который призвана была дать созданная им «истинная религия», в которой он отрицал богословские аспекты церковных учений и в связи с этим роль церкви в общественной жизни. Этику религиозного самосовершенствования человека он связывал с отказом от какой-либо борьбы, с принципом непротивления злу насилием, с проповедью всеобщей любви. Считая всякую власть злом, Толстой пришел к идее отрицания государства. Поскольку в общественной жизни он отвергал насильственные методы борьбы, постольку считал, что упразднение государства должно произойти путем отказа каждого от выполнения общественных и государственных обязанностей. А религиозно-нравственное самосовершенствование человека должно было дать ему определенный душевный и социальный порядок.

Толстой был последовательным и убежденным антигосударственником. В своих художественных творениях Толстой апеллировал к народу как носителю истинной веры и нравственности, считая его основой всего общественного здания. На мировоззрение Толстого оказали огромное влияние Руссо, Кант, Шопенгауэр [32, с. 52-56]. Разнообразные взгляды Толстого оказались созвучными определенной части русского и зарубежного общества, выраженном в религиозно-политическом движении толстовства, идеями которого были не только сугубо религиозные, но и общественно-политические, главным образом связанные с идеями пацифизма, «ненасильственных методов» борьбы за равенство и социальную справедливость. Религиозно-философские идеи Толстого стали концепцией движения толстовства, основанного на началах «опрощения» и «непротивления злу насилием». Последователи его учения почитали провозглашенные им пять заповедей: не гневайся, не прелюбодействуй, не клянись, не противься злу насилием, возлюби врагов своих как ближнего своего. В последние годы жизни Толстого его борьба против несправедливого общественного устройства и его охранителей приобрела поистине титанический и героический характер.

\section{Библиография:}

1. Багаутдинов Ф.Н. Лев Николаевич Толстой. Музы и право. Казань: Татарское книжное издательство, 2010. С. 13-26.

2. Галаган Г.Я. Л.Н. Толстой. Художественно-этические искания. Диссертация на соиск. уч. ст. Д. фил. наук. Л., 1984. 373 с.

3. Глущенко С.С. Социально-педагогические воззрения Л.Н. Толстого: автореф. дис. ... канд. педагогич. наук / Ин-т соц. - пед. проблем сельской школы РАО М., 200420 с. 
4. Графский В. Г., Золотухина Н. М., Мамут Л. С., Нерсесянц В. С., Сюкияйнен Р.Л. История политических и правовых учений. М.: Норма-Инфра-М, 2001. С. 736.

5. Гулин А. В. Л.Н. Толстой: духовный идеал и художественное творчество :1850-1870-е годы: автореферат дис. ... доктора филологических наук в форме науч. доклада / Институт литературы им. м. Горького РАН. М., 2004. 64 с.

6. Гулин А. В. Лев Толстой и дороги русской истории. М.: ИМЛИРАН, 2004. 254 c.

7. Гусев Н.Н. Л.Н. Толстой в 1863-1869. Ч. 12. 1855-1869, 1957. Т. 14. М., 1935.

8. Журина О. В. Роман “Воскресение” в контексте творчества позднего Л. Н. Толстого: модель мира и ее воплощение: автореферата дис. ... канд. филол. наук / Карельский Государственный Педагогический Университет. Петрозаводск, 2002. $94 \mathrm{c}$.

9. Емельянова И.А. Лев Толстой на юридическом факультете Казанского университета // Советское государство и право. 1979. № 11. С. 20-22.

10. Кони А.Ф. Воспоминания о писателях. М.: Правда, 1989. 656 с.

11. Кони А.Ф. Лев Николаевич Толстой // Л.Н. Толстой в воспоминаниях современников. В 2-х т. Т. 2. М.: Художественная литература, 1978. С. 173-196.

12. Куприц Н.Я. Критика царизма и его государственного аппарата в произведениях Льва Толстого // Советское государство и право. 1978. № 6. С. 97-105.

13. Л.Н. Толстой в воспоминаниях современников. В 2-х т. Т. 1. М.: Художественная литература, 1978. 621 с.

14. Л.Н. Толстой в воспоминаниях современников. В 2-х т. Т. 2. М., Художественная литература, 1978.671 с.

15. Л.Н. Толстой: pro et contra: Личность и творчество Льва Толстого в оценке русских мыслителей и исследователей. Антология. СПб.: Издательство Русского Православного Христианского Института, 2000. 984 с.

16. Толстой Л.Н. Собрание сочинений в 22 томах. Т. 18. Письма. 146. А.А. Толстой. 1861. Август. М.: Художественная литература, 1984. 899 с.

17. Лев Толстой: Полное собрание сочинений. Сер. 1. “Художественные произведения”. Т. 38. 1909-1910. М.: Художественная литература, 1936. 619 c. // http://tolstoy.ru/creativity/90-volume-collection-of-the-works/

18. Ломунов К.Н. Лев Толстой о романе “Воскресение”. М., 1991. С. 8-12.

19. Лученецкая-Бурдина И.Ю. Проза Л. Н. Толстого в литературном контексте 1870-1890-х гг.: дисс. ... доктора филологических наук. М., 2002. 365 с.

20. О религии Льва Толстого. Собрание сочинений. М.: Путь. 248 с.

21. Ореханов Ю.Л. Русская Православная Церковь и Л.Н. Толстой: конфликт глазами современных мыслителей. М.: Изд-во НОУ ВПО “ПСТГУ", 2010. 696 с.

22. Ореханов Ю.Л. Историко-культурный контекст дихотомии «Русская православная церковь. Л. Н. Толстой»: автореферат дис. ... доктора исторических наук / ФГБОУ ВПО «Ярославский государственный педагогический университет им. К.Д. Ушинского». Ярославль, 2012. 47 с.

23. Ореханов, Ю. Л. Л. Н. Толстой и В. Г. Чертков. К истории завещания писателя. М.: Изд-во НОУ ВПО «ПСТГУ», 2009. $192 \mathrm{c.}$

24. Очерки истории Санкт-Петербургской епархии. СПб.: Андреев и сыновья, 1994. 318 с.

25. Сухотина-Толстая Т. Л. Воспоминания. М.: Художественная литература, 1980. 528 с.

26. Сушкова Ю.Н. Под небом Канады. Саранск: Изд-во Мордов. Ун-та, 2013. С. 242.

27. Тарасов Андрей Борисович. Праведники и праведничество в позднем творчестве Л.Н. Толстого: дис. ... канд. филол. наук. М., 1998203 с.

28. Толстой Л. Н. Путь жизни. М.: Республика, 1993. 431 с.

29. Alston C. Tostoy’s Guiding Light // History Today. № 60. 2010.

30. Davis R.H. A Report on the Third Seminar on Tolstoy and America // Tolstoy Studies Journal. 1989. Vol. 2. P. 109-113.

31. Donskov A. Leo Tolstoy and the Canadian Doukhobors: A Historic Relationship. Ottawa: Centre for Research on CanadianRussian Relations, Carleton University, 2005. P. 473.

32. Draganov A. Socratic and Kantian Ideas in Virtue in Anna Karenina // Tolstoy Studies Journal. 2013. Vol. XXV. P. 52-56.

33. Fraiman-Morris S. Stefan Zweig's "Untergang eines Herzens" a Version of Tolstoy's "The Death of Ivan Iliych". Conditio Judaica. 62. Studien und Quellen zur Deutsch-Judischen Literatur und Kulturgeschichte. Max Niemeyer Verlag, Tubingen: Walter de Gruyter GmbH \& Co. KG, 2007. P. 107-115.

34. Gustafson R.F. Introduction. L.N. Tolstoy. Resurrection. Reissue. Translated by Louise Maude with an Introduction and Notes by Richard F. Gustafson. Oxford: Oxford University Press, 2009. P. Viii-x.

35. Hooper C. Vladimir Solov’ev and Lev Tolstoy on Eros and Ego // Russian Review. 2001. № 60.3ю P. 360-380.

36. Irwin W. Death by Inauthenticity: Heidegger's Debt to Ivan Il'ich's Fall // Tolstoy Studies Journal. 2013. Vol. XXV. P. $15-22$.

37. Kokobodo A. Estranged and Degraded Worlds: the Grotesque Aesthetics of Tolstoy's Resurrection. Tolstoy Studies Journal. 2012. V. XXIV. P. 1-15.

38. Mahatma Gandhi and Leo Tolstoy Letters. Collection / Ed. with Introduction and Notes by B. Srinivasa Murthy. Foreword by Virginia Hartt Ringer. Long Beach, CA: Long Beach Publications, 1987. P. 81.

39. Paperno I. "Who, What Am I?": Tolstoy Struggles to Narrate the Self. Ithaka, NY: Cornell University Press, 2014. P. 288.

40. Pinel C. Leo Tolstoy: Author and Anarchist // Social Standard. 1987. № 993, May.

41. Schonle A. Tolstoy's Critique of Modernity in War and Peace// Tolstoy Studies Journal. 2013. Vol. XXV. P. $42-52$.

42. Toland K. Path of Life: Lev Tolstoy’s Prescriptive Spiritual Diaries // Tolstoy Studies Journal. Vol. XXIV. P. 15-26. 
43. Tolstoy L.N. On Life and Essays on Religion. Oxford: Oxford University Press, 1934. P. 270.

44. Tolstoy L.N. War and Peace. Reissue. New York, N.Y.: Simon \& Schuster, 2014. P. 1024.

45. Zweig S. The Living Thought of Tolstoy. Greenwich: Fawcett Publications, 1963. P. 124.

\section{References (transliterated):}

1. Bagautdinov F.N. Lev Nikolaevich Tolstoi. Muzy i pravo. Kazan': Tatarskoe knizhnoe izdatel'stvo, 2010. S. 13-26.

2. Galagan G.Ya. L.N. Tolstoi. Khudozhestvenno-eticheskie iskaniya. Dissertatsiya na soisk. uch. st. d. fil. nauk. L., 1984.373 s.

3. Glushchenko S.S. Sotsial'no-pedagogicheskie vozzreniya L.N. Tolstogo : avtoref. dis. ... kand. pedagogich. nauk / In-t sots. - ped. problem sel'skoi shkoly RAO M., 200420 c.

4. Grafskii V. G., Zolotukhina N. M., Mamut L. S., Nersesyants V. S., Syukiyainen R.L. Istoriya politicheskikh i pravovykh uchenii. M.: Norma-Infra-M, 2001. S. 736.

5. Gulin A. V. L.N. Tolstoi: dukhovnyi ideal i khudozhestvennoe tvorchestvo :1850-1870-e gody: avtoreferat dis. ... doktora filologicheskikh nauk v forme nauch. doklada / Institut literatury im. m. Gor'kogo RAN. M., 2004. 64 s.

6. Gulin A. V. Lev Tolstoi i dorogi russkoi istorii. M.: IMLIRAN, 2004. 254 s.

7. Gusev N.N. L.N. Tolstoi v 1863-1869. Ch. 12. 1855-1869, 1957. T. 14. M., 1935.

8. Zhurina O. V. Roman "Voskresenie" v kontekste tvorchestva pozdnego L. N. Tolstogo: model' mira i ee voploshchenie: avtoreferata dis. ... kand. filol. nauk / Karel'skii Gosudarstvennyi Pedagogicheskii Universitet. Petrozavodsk, 2002. $94 \mathrm{~s}$.

9. Emel'yanova I.A. Lev Tolstoi na yuridicheskom fakul'tete Kazanskogo universiteta // Sovetskoe gosudarstvo i pravo. 1979. № 11. S. 20-22.

10. Koni A.F. Vospominaniya o pisatelyakh. M.: Pravda, 1989. $656 \mathrm{~s}$.

11. Koni A.F. Lev Nikolaevich Tolstoi // L.N. Tolstoi v vospominaniyakh sovremennikov. V 2-kh t. T. 2. M.: Khudozhestvennaya literatura, 1978. S. 173-196.

12. Kuprits N.Ya. Kritika tsarizma i ego gosudarstvennogo apparata v proizvedeniyakh L'va Tolstogo // Sovetskoe gosudarstvo i pravo. 1978. № 6. S. 97-105.

13. L.N. Tolstoi v vospominaniyakh sovremennikov. V 2-kh t. T. 1. M.: Khudozhestvennaya literatura, 1978. $621 \mathrm{s.}$

14. L.N. Tolstoi v vospominaniyakh sovremennikov. V 2-kh t. T. 2. M., Khudozhestvennaya literatura, 1978. $671 \mathrm{~s}$.

15. L.N. Tolstoi: pro et contra: Lichnost' i tvorchestvo L'va Tolstogo v otsenke russkikh myslitelei i issledovatelei. Antologiya. SPb.: Izdatel'stvo Russkogo Pravoslavnogo Khristianskogo Instituta, 2000. 984 s.

16. Tolstoi L.N. Sobranie sochinenii v 22 tomakh. T. 18. Pis'ma. 146. A.A. Tolstoi. 1861. Avgust. M.: Khudozhestvennaya literatura, 1984. $899 \mathrm{~s}$.

17. Lev Tolstoi: Polnoe sobranie sochinenii. Ser. 1. "Khudozhestvennye proizvedeniya". T. 38. 1909-1910. M.: Khudozhestvennaya literatura, 1936. 619 s. // http://tolstoy.ru/creativity/90-volume-collection-of-the-works/

18. Lomunov K.N. Lev Tolstoi o romane "Voskresenie". M., 1991. S. 8-12.

19. Luchenetskaya-Burdina I.Yu. Proza L. N. Tolstogo v literaturnom kontekste 1870-1890-kh gg.: diss. ... doktora filologicheskikh nauk. M., 2002. $365 \mathrm{~s}$.

20. O religii L'va Tolstogo. Sobranie sochinenii. M.: Put'. 248 s.

21. Orekhanov Yu.L. Russkaya Pravoslavnaya Tserkov' i L.N. Tolstoi: konflikt glazami sovremennykh myslitelei. M.: Izd-vo NOU VPO "PSTGU", 2010. $696 \mathrm{~s}$.

22. Orekhanov Yu.L. Istoriko-kul'turnyi kontekst dikhotomii «Russkaya pravoslavnaya tserkov’. L. N. Tolstoi»: avtoreferat dis. ... doktora istoricheskikh nauk / FGBOU VPO «Yaroslavskii gosudarstvennyi pedagogicheskii universitet im. K.D. Ushinskogo». Yaroslavl', 2012. $47 \mathrm{~s}$

23. Orekhanov, Yu. L. L. N. Tolstoi i V. G. Chertkov. K istorii zaveshchaniya pisatelya. M.: Izd-vo NOU VPO «PSTGU», 2009.192 s.

24. Ocherki istorii Sankt-Peterburgskoi eparkhii. SPb.: Andreev i synov'ya, 1994. $318 \mathrm{s.}$

25. Sukhotina-Tolstaya T. L. Vospominaniya. M.: Khudozhestvennaya literatura, 1980. $528 \mathrm{~s}$.

26. Sushkova Yu.N. Pod nebom Kanady. Saransk: Izd-vo Mordov. Un-ta, 2013. S. 242.

27. Tarasov Andrei Borisovich. Pravedniki i pravednichestvo v pozdnem tvorchestve L.N. Tolstogo: dis. ... kand. filol. nauk. M., $1998203 \mathrm{~s}$.

28. Tolstoi L. N. Put' zhizni. M.: Respublika, 1993. 431 s.

29. Alston C. Tostoy’s Guiding Light // History Today. № 60. 2010.

30. Davis R.H. A Report on the Third Seminar on Tolstoy and America // Tolstoy Studies Journal. 1989. Vol. 2. P. 109-113.

31. Donskov A. Leo Tolstoy and the Canadian Doukhobors: A Historic Relationship. Ottawa: Centre for Research on CanadianRussian Relations, Carleton University, 2005. P. 473.

32. Draganov A. Socratic and Kantian Ideas in Virtue in Anna Karenina // Tolstoy Studies Journal. 2013. Vol. XXV. P. 52-56.

33. Fraiman-Morris S. Stefan Zweig's "Untergang eines Herzens" a Version of Tolstoy's "The Death of Ivan Iliych". Conditio Judaica. 62. Studien und Quellen zur Deutsch-Judischen Literatur und Kulturgeschichte. Max Niemeyer Verlag, Tubingen: Walter de Gruyter GmbH \& Co. KG, 2007. P. 107-115.

34. Gustafson R.F. Introduction. L.N. Tolstoy. Resurrection. Reissue. Translated by Louise Maude with an Introduction and Notes by Richard F. Gustafson. Oxford: Oxford University Press, 2009. P. Viii-x.

35. Hooper C. Vladimir Solov’ev and Lev Tolstoy on Eros and Ego // Russian Review. 2001. № 60.3yu P. 360-380.

36. Irwin W. Death by Inauthenticity: Heidegger's Debt to Ivan Il'ich's Fall // Tolstoy Studies Journal. 2013. Vol. XXV. P. 15-22. 
DOI: $10.7256 / 1811-9018.2016 .9 .19129$

При цитировании этой статьи сноска на dоі обязательна

Правовая и политическая мысль

37. Kokobodo A. Estranged and Degraded Worlds: the Grotesque Aesthetics of Tolstoy’s Resurrection. Tolstoy Studies Journal. 2012. V. XXIV. P. 1-15.

38. Mahatma Gandhi and Leo Tolstoy Letters. Collection / Ed. with Introduction and Notes by B. Srinivasa Murthy. Foreword by Virginia Hartt Ringer. Long Beach, CA: Long Beach Publications, 1987. P. 81.

39. Paperno I. "Who, What Am I?": Tolstoy Struggles to Narrate the Self. Ithaka, NY: Cornell University Press, 2014. P. 288.

40. Pinel C. Leo Tolstoy: Author and Anarchist // Social Standard. 1987. № 993, May.

41. Schonle A. Tolstoy's Critique of Modernity in War and Peace // Tolstoy Studies Journal. 2013. Vol. XXV. P. $42-52$.

42. Toland K. Path of Life: Lev Tolstoy's Prescriptive Spiritual Diaries // Tolstoy Studies Journal. Vol. XXIV. P. 15-26.

43. Tolstoy L.N. On Life and Essays on Religion. Oxford: Oxford University Press, 1934. P. 270.

44. Tolstoy L.N. War and Peace. Reissue. New York, N.Y.: Simon \& Schuster, 2014. P. 1024.

45. Zweig S. The Living Thought of Tolstoy. Greenwich: Fawcett Publications, 1963. P. 124. 